\title{
NOTES ABOUT THE WIVES OF CHRIST (SPONSAE CHRISTI) AND THE MARRIED WOMEN IN DE HABITU VIRGINUM OF CYPRIAN OF CARTHAGE ${ }^{1}$
}

\author{
Rosa Mentxaka ${ }^{2}$
}

\begin{abstract}
Following a brief introduction, this paper will then focus on Cyprian's comments regarding the behaviour of Virgins in De Habitu Virginum. Cyprian of Carthage argues with the adulterium, a category of Roman criminal law which was particularly important in contemporary society, in order to justify the requirement for Virgins to adopt a way of life and behaviour that would be described today as "well-behaved and discreet". Although fully aware that married women had a different way of life to sponsae Christi, he was inclined to impose the same rules on allChristian Women.
\end{abstract}

Key words: Cyprian of Carthage, the Dress of Virgins, sponsae Christi, adulterium, Virgins, Christian women.

Título en español: Nota mínima sobre las esposas de Cristo (Sponsae Christi) y las mujeres casadas en el De habitu virginum de Cipriano de Cartago

Resumen: El trabajo, tras una primera parte introductoria, se centra en el comentario de algunos párrafos dedicados al comportamiento de las vírgenes. Cipriano no pudo resistir la tentación de argumentar con una categoría jurídica penal romana, particularmente grave en la sociedad laica de la época, el adulterium, para justificar la necesidad de que las vírgenes adoptaran una forma de vivir, de estar en sociedad, que podríamos calificar de recatada y discreta; tampoco dudó en extender estas pautas a todas las mujeres cristianas, si bien fue plenamente consciente de que las mujeres casadas desarrollaron formas de vida distintas de las vírgenes.

Palabras clave: Cipriano de Cartago, De habitu virginum, sponsae Christi, adulterium, vírgenes, mujeres cristianas.

\footnotetext{
${ }^{1}$ Date of reception: 02/09/2013

Date of acceptance: $17 / 11 / 2013$

These pages should be inserted in the project of research I + D: DER 2010-18019/JURI as well as in the activity carried out by the Research Group of the EHU13/06: Cristianismo y Derecho Romano and I would like to dedicate to Prof. Dr. Olga Tellegen.

2 Professor of Roman Law, Departamento de Derecho Romano y Eclesiástico, Universidad del País Vasco/Euskal Herriko Unibertsitatea, Spain; $\bowtie$ rosa.mentxaka@ehu.es.
} 


\section{Introduction}

The interest of this article resides in expounding on various references that we find in a work of Cyprian of Carthage dedicated to the outer clothing of the virgins and the behavior expected of them (De habitu virginum) and about the marriage of the wives of Christ. As we will have the opportunity to appreciate in the fifth section of the paper (the previous four are introductory and will be devoted to conceptualization of the topic, discussion of the author, his work and virginity in early Christianity), Cyprian has no theoretical problem in differentiating enforceable behaviors in society for Christian women, depending on whether they are virgins or whether they are wives of mortal men; he advocates the same guidelines for living for all because, ultimately, the work formally addressed to the virgins reflects his vision for the behavior required of all Christian women in society.

The Carthaginian Bishop, as a superb rhetor, demonstrates a great command of language and in these pages I will try to analyze: a. first, the technique of argument used in the construction of his speech in order to "persuade" and convince the virgins to follow his prescribed patterns of life; b. second, the lexicon used for this, in which we find a particularly severe roman criminal legal category from the secular society of the time: the adulterium. The father of the Church cannot resist the temptation to use such a crime to refer to the virgins who develop a style of life that, according to him, is reprehensible and incompatible with their status and therefore to substantiate the need to change it and introduce a pattern of behavior which we could describe as demure, humble and discreet.

\section{Virginity in early Christianity ${ }^{3}$}

In Schollgen's (2001: 547 ss.) opinion, since its origins, Christianity embraced the demand of virginity ${ }^{4}$ linked to the prohibition of sexual relations outside marriage,

\footnotetext{
${ }^{3}$ I have discussed the subject in detail in Mentxaka 2010: 27 ss. and in Mentxaka 2013: 75-80.
} 
because in some writings of the New Testament ${ }^{5}$, valuation of sexual abstinence for both sexes was already present ${ }^{6}$. However, in the first two centuries there are no great testimonies of people who proclaim themselves celibates ${ }^{7}$; the reason for this, it is said, is that the primitive Christian communities were constituted by people who, having converted to Christianity, were usually already married or had had sexual relations; thus resulting, in practice, in a greatly restricted number of celibates.

Without claiming to be exhaustive in the exposure of the specific positions of the various Christian Fathers (vid. Mentxaka 2010: 39 ss.), who basically advocated the abstinence of sexual intercourse ${ }^{8}$, I will refer briefly to the approach another African Church Father had on this issue, Tertullian (ca. 160 - ca. 225) ${ }^{9}$ who, as it is known, developed his pastoral activity in the same city as our Bishop and constituted a clear point of reference for him.

Tertullian is thought to be the first author who, in the work devoted to the veil of the virgins ${ }^{10}$, expressly proposed that women could be incorporated in a state of virginity $^{11}$. However, according to experts ${ }^{12}$ and despite the role played in his writings,

\footnotetext{
${ }^{4}$ On the meaning that the term virginity had for both men and women in early Christianity, how it evolved and the consequences of its practice see Brown 1985: 427 ss.; also of great interest the synthesis of Castelli 1986: 373 ss.

${ }^{5}$ See Martínez 1913: 19-38; Vizmanos 1949 = reedition 2009: 12 ss.; Giesen 1996: 1097; Guillén 2000: 321, and Ramis 1990: 18 ss., where he exposes the virgins and widows' references in the New Testament. ${ }^{6}$ Note that Paul professes celibacy and therefore, he invites all people to live this kind of life in the first letter to the Corinthians: 7, 7-9; traditionally their words have been considered as a recommendation of Paul to stay chaste as it constitutes a state superior to marriage; on this and other Pauline passages referring to virginity, see, for example, Dauvillier 1970: 353-354; McNamara1976: 151; Brown 1993: 75 ss.; MacDonad 1996: 127 ss.; Ramis 1990: 19 ss.; and Vizmanos 1949 = reedition 2009: 32 ss.

${ }^{7}$ See, for example, Brown 1993: 104 ss.; Schöllgen 201: 548 ss. and Dauvillier 1970: 355-357 which alludes to the existence of virgins dedicated to the affairs of the Lord from Early Apostolic times without specifying details.

${ }^{8}$ In this regard, see, for example, Radford Ruether 1974: 165 ss.

${ }^{9}$ About his life, see for example the references I give in 2010: 47 n. 130.

${ }^{10}$ About De Virginibus velandis, see the cited bibliography in Mentxaka 2010: 48 n. 131.

${ }^{11}$ De Virg. Vel. 9, 1, ss.; see for example: Martínez 1913: $73-90$ and Ramos Lissón 2009: 147 according to whom, the African Father emphasizes the value of perfect chastity in various works: a. - in Apol. 9, 19, where he argues the superior status of Christians with regard to the corrupt pagan society; b. - in Exh. Cast. I, 45, that, along the lines of what was done in the Apostolic Tradition $(10,12)$ to establish the hierarchy of states of life, placed the virgins first, then widows and finally married people and c. - in De Virg. Vel. 1, 2-3, where he emphasizes the greater merit of the celibacy of men compared to women.

${ }^{12}$ See sources and bibliography in Schöllgen 2001: 554.
} 
a theology evolved of virginity is still not encountered, although some of its elements had already begun to appear; it is remarkable, by the reference that we will find in our text, that Tertullian was the first Christian writer who used the metaphor of marriage as an element of union between the virgins and Christ; he considered that the virgin was united in marriage with Christ and therefore spoke of her as sponsa Christi ${ }^{13}$.

With this precedent, it should not surprise us that, in the light of the remarkable growth and extension of virginity in the Christian society of his time, Cyprian of Carthage was, particularly in his work De habitu virginum, the first who treated virgins as a separate category within the Christian Church $^{14}$. It is probably necessary to relate the voluntary renunciation of marriage to the parusia $^{15}$; the hope for the second coming of Christ and the imminent end of the world that explained the justification for foregoing procreation and giving extension to continence in the bosom of Christianity. As related to women, in the middle of the $3^{\text {rd }}$ century A. D., it seems that the decision to remain a virgin was not accompanied by a public act of consecration or public demonstration of the vote of chastity ${ }^{16}$; in Ramis' opinion (1990: 23 ss., in special page 29)" we will have to wait to the last years of the fourth century to have news of a "consecration of virgins" and of the institutionalization of the ordo viginum ${ }^{17}$.

\footnotetext{
${ }^{13}$ About this expression as used by the Fathers see, for example, García Villoslada 1978: 617; Testard 1981: 181-183; and Vizmanos $1949=$ reedition 2009: 151 ss.

${ }^{14}$ See Brown 1993: 269 ss. On the other hand, Keenan (1958: 25-26) supports only as probable that this is one of the first treatises of this nature found in Christian literature.

${ }^{15}$ McNamara (1979: 584) highlights the impact that the idea of the parusia had in primitive Christianity; Tibiletti (1979: 432 ss.) exposes this aspect in regards to Cyprian; for both Tertullian and Cyprian, the rule of continence is not something personal but collective; both Fathers invite mankind to adapt its behavior to the coming of Christ, as being virgins in this life, have already been advanced towards theglory of the resurrection; according to Tibiletti, the teaching of Cyprian is not the result of a doctrinal basis but of his own experience. In Spanish literature it is necessary to mention Pedregal Rodríguez 2007: 420-421 and Viciano 2006: 572.

${ }^{16}$ In this sense: Keenan 1958: 27. On the evolution of the vote see Vizmanos $1949=$ reedition 2009: 142147.

${ }^{17}$ In the opinion of some specialists, in the 4th century, in the triumphant Christian Church, there were families in which virginity was valued in particular; this facilitated considerably the process of its institutionalization, as we have seen, of the first steps that had been taken in previous centuries. At this historic moment, we find the virgins' group (ordo virginum) within the Church regulated with criteria for acceptance and rules of behavior in accordance with the religious provisions and still with very varied forms of life: from life secluded in the monastery to the secular life in the family home. In this regard, for example, see Krawiec 2002: 121 ss. with the corresponding notes on pages 223 ss.; Castelli 1986: 78 ss.;
} 


\section{The work: De habitu virginum (On the dress of the virgins)}

The literary activity of Cyprian of Carthage ${ }^{18}$, according to Quasten (2001: $639)^{19}$, was provoked by particular circumstances and responded to practical purposes ${ }^{20}$; his treatises and letters were widely distributed and were much appreciated in the churches of the West ${ }^{21}$; the first to bring these works together was his deacon biographer Pontio, who has allowed us to preserve his work almost in full ${ }^{22}$. His writings are usually classified into three sections: a. treaties; b. collections of letters and c. the Appendix containing the Apocrypha. Amongst the treaties is a subgroup that refers

and Vizmanos 1949 = reedition 2009: 469 ss.; Clarke (1987: 19, 115 ss.) exposes the enthusiasm for asceticism within Christianity during the 4th and the beginning of the 5th centuries; the women who joined this movement were usually aristocrats willing to renounce the wealth and social respect attached to their origins. Page 291994 = reprint 2004: 25 ss., analyzes the development of ascetic ideas in Asia Minor and Egypt, in Christian society as the Fathers of the Church formed a certain theology in this regard, particularly from the 4th century. Cameron (1991: 171-180) develops this topic in Christian literature of the 4th century.

${ }^{18}$ Cyprian was born, probably in Carthage, around the year 205 in a fairly affluent family that gave him, in accordance with his status, a good education for his time: studies in literature and rhetoric. Before converting to Christianity we find him in his hometown as a reputed rhetor, and from the hand of the priest Cecilian (apparently in the year 246) joined the community of Carthage. With some opposition he was elected successor to Bishop Donatus sometime in 248 or 249 . Shortly after his election took place the persecution of Decius (249-251) led him to be absent from his headquarters and to return only at the end of the same; back in Carthage he was quiet until, owing to the Edict issued in August of the 257 by Valerian, was exiled. When he learned of the possible measures to be taken by Valerian and Gallienus, on the occasion of the second Edict of persecution, he returned to Carthage, where he was arrested and died after conviction on 14 September 258. A major bibliography on his person, his work and their transmission, as well as its meaning and influence can be found in Mentxaka 2010: 15-22 and Johnson 2009: 145-148.

${ }^{19}$ Also Dell'Osso (2006: 19) emphasizes that his work is not the reflection of a scholastic or a theologian but the action of a believer, bishop and pastor of souls.

${ }^{20}$ Fernández Ubiña (1981: 220) also stresses that the Bishop devoted all his attention to the internal organization of communities, trying to solve the problems posed by schisms and heresies and thus contributed to the development of a hierarchical regulatory scaffolding that came to support for the Church as a quasi-state organization within the State.

${ }^{21}$ In this sense: Campos 1964: 35.

${ }^{22}$ Campos (1964: 35) thinks that some letters have been lost, as well as some sermons and a stenographic dictionary that became known in the Renaissance. According to a persistent tradition, the Bishop of Carthage re-stated the tironians notes, completing and adapting them for use by Christians. 
to disciplinary writings which include the work I am going to mention and briefly comment on in the following paragraphs: De habitu virginum ${ }^{23}$.

We have before us a brief work ${ }^{24}$ in which, according to Schöllgen (2001: 555 followed by Viciano 2006: 573), Cyprian directed, first and foremost, to wealthy women of the Carthaginian community who, despite having opted for virginity, were not willing to change their lifestyle; clearly in this writing the Bishop tries to convince them to change it because they do not demonstrate the appropriate patterns of life in accordance with the status of Christian virgins ${ }^{25}$.

It is not the first time that a father of the Carthaginian Church had approached the women of elevated economic standing. Tertullian had already earmarked some of his writings for, e. g. De cultu feminarum or De virginibus velandis, this group (Guillén 2000: 321; Schöllgen 1984: 203-207 and Viciano 2006: 573-577) ${ }^{26}$. It seems clear that the Christian community of the African capital had a group of women who belonged to higher social groups in a broad sense ${ }^{27}$ and could afford to include in their attire expensive objects, refined jewelry, elegant clothes, pearls, etc. At the time of Cyprian, in light of the claims that we find in parts of the work, it seems certain that these affluent women continued to have a presence in the community and the Bishop, to develop his pastoral work, aimed especially at them and tried to "persuade" them

\footnotetext{
${ }^{23}$ Dell'Osso 2006: 21-22; Gülzow - Wlosok 1997: 560-561; Quasten 2001: 643; and Vizmanos $1949=$ reedition 2009: 90.

${ }^{24}$ Watson (1920-1921: 361) says that we are in front of a homily. Bernard Donna (1946: 399-407) speaks about the influence that this work of Cyprian had on the work De Virginitate (addressed to the nuns at Barking) of the British writer of the $7^{\text {th }}$ century, Aldhelm.

${ }^{25}$ In this sense: Stahlmann 1997: 199.

${ }^{26}$ Viciano highlights the dependence of Cyprian on two treatises of Tertullian: De virginibus velandis and De Cultu feminarum and of the Greco-Roman, Jewish, and Christian anthropology according to which the woman was a lower human being, a fact that leads him to conclude to Tertullian that women should be excluded from the functions of Church Government. Keenan (1958: 29) highlights the dependence of Tertullian not only respect these two cited works but also of De pudicitia and De Exhortatione castitatis. About this question: Bernard Donna (1946: 399 n. 1) cites the doctoral dissertation dedicated to this issue, of sister Angela Elisabeth Keenan 1932: 10-27, that I have not read.

${ }^{27}$ Watson (1920-1921: 365), based on the content of this work, argues that already before Constantine in the Christian communities there could be people of great economic capacity. Along the same lines: Schöllgen (1984: 175) accepts as quite probable that women from the Senatorial Order formed part of the Carthaginian community; on page 205, it also states that there could be women belonging to the Decurional Order and believed that, no doubt outside of these groups, women from higher social groups existed in Carthage, in the broad sense.
} 
through the letter-sermon of the need to accept ecclesiastical discipline ${ }^{28}$, a form of behavior, in which simplicity, humility, obedience and sexual abstinence constituted its referential elements.

We do not know exactly when Cyprian wrote this work; the fact that there is no mention of persecutions has led specialists to argue that it might have been produced in the early period; therefore, usually it is put in relation to the Council of 249 and therefore drafted before $250^{29}$, although at the time I pointed out an interpretive alternative proposal to this, resulting from relating certain aspects of this work with the fourth letter of Cyprian's correspondence, a letter which, in my opinion, is at the earliest, mid-May of $253^{30}$.

\section{The virgins as "wives" of Christ}

The metaphor of the virgin as the wife of Christ played a very important role in the construction of the theology of virginity. As we will have the opportunity to appreciate, the Carthaginian Bishop at various points of his work (see Mentxaka 2010: 61 ss.), and in particular in this now discussed, qualifies the virgins as "wives" of Christ. Yet, as I have already said ${ }^{31}$, this metaphor was not original of Cyprian, but Tertullian, who was the first Christian writer to use it; according to him, the virgin was united in marriage with Christ: was the sponsa Christi. However, curious in this regard, if we accept what Gerlitz (1989: 116) says, is that this image was not a creation of

\footnotetext{
${ }^{28}$ Highlighting the approach to this work as a result of the pastoral work of the Bishop, see Dunn 2005 a: 205, 208 and idem 2005 b: 295.

${ }^{29}$ This work has usually been located at the beginning of the episcopate; see, for example, Deléani 2007: 96; Guillén 2000: 319; Gülzow - Wlosok 1997: 561; Viciano 2006: 571 ss. and Watson 1920-1921: 361 ss.

${ }^{30}$ I (2010: 26, 71-77) interpret that if we put in relation De habitu virginum and the fourth letter of the correspondence of Cyprian (that in my interpretative hypotheses could have written from mid-May of the year 253 until the end of August of 257) its drafting probably could have been delayed. If on the contrary, we believe that no such relationship exists, or if it does exist, this does not necessarily imply a simultaneity in the drafting of both writings. It could be accepted that the writing could date from the first part of his episcopate while the fourth letter could be from a later stage.

${ }^{31}$ See note 13.
} 
Tertullian but was taken from the pagan world; in Roman society, the vestal virgin was already considered, on the one hand, the incarnation of the goddess and, on the other, the wife or woman of God.

In the development of the theology of virginity, the forms of the consecration of virgins did nothing more than transpose the behavior characteristic of wives and apply them to the relationship between the virgin and Christ, the parameters of behavior that existed between husband and the wife in an earthly marriage. The sign signifying that the virgin was the wife of Christ, according to Vizmanos (1949 = reedition 2009: 159161) and Ramis (1990: 194 ss.), was the veil which was imposed on the day of consecration: velatio virginis was the same as velatio sponsae, although with another significance.

\section{Some references to the behavior required of the "wives" of Christ and, by extension, of all married Christian women}

As I have already said, with this booklet the Carthaginian Father seeks to educate the Christian virgins whilst warning them of the precautions that should be taken against the many temptations that will be found during their daily lives, temptations he specifies for example: to flaunt $\operatorname{goods}^{32}$, to comb to draw attention ${ }^{33}$, to

\footnotetext{
${ }^{32}$ Paragraph 7: Sed sunt aliquae divites et facultatum ubertate locupletes, quae opes suas praeferant et se bonis suis uti debere contendant. .... . Ceterum, quaecumque terrena sunt in saeculo accepta et hic cum saeculo remansura, tam contemni debent quam mundus ipse contemnitur, cuius pompis et deliciis iam tunc renuntiavimus cum meliore transgressu ad Deum venimus... = "But there are some women who are wealthy and rich in the abundance of their possessions, who display their riches and who argue that they ought to use the blessings that are theirs... But the things that are earthly, that have been acquired in the world and will remain here with the world, should be despised just as the world itself is despised, whose pomps and pleasures we already renounced at the time that we came to God by passing to a better way" (translation of Keenan 1958: 37).

${ }^{33}$ Paragraph 9: Ceterum, si tu te sumptuosius comas, et per publicum notabiliter incedas, oculos in te iuventutis illicias, suspiria adolescentium post te trahas, concupiscendi libidinem nutrias, suspirandi fomenta succendas, ut etsi ipsa non pereas, alios tamen perdas, et velut gladium te et venenum videntibus praebeas, excusari non potes quasi mente casta sis et pudica. = "But if you adorn yourself too elaborately and appear conspicuous in public, if you attract to yourself the eyes of the youth, draw alter you the sighs of young men, foster the desire of concupiscence, enkindle the fire of hope, so that, without perhaps losing your own soul, you neverthless ruin others and offer yourself a sword and poison, as it were to
} 
wear ostentatious clothes ${ }^{34}$, to adorn $^{35}$, to paint the face and dye hair ${ }^{36}$, attending weddings and banquets ${ }^{37}$; to go to the baths ${ }^{38}$, etc.; Cyprian informs such women that if with discipline they shy away from such temptations ${ }^{39}$ and if they are faithful to their only husband, Christ, they will receive glory as a reward.

those who behold you, you cannot be excuse don the ground that your mind is chaste and pure" (translation of Keenan 1957: 39).

${ }^{34}$ Paragraph 12: Ornamentorum ac vestium insignia et lenocinia formarum non nisi prostitutis et impudicis feminis congruunt, ... = "Showy adornments and clothing and the allurements of beauty are not becoming in any except prostitutes and shameless women.... "; Paragrafo 13: Seticum et purpuram indutae Christum induere non possunt ... = "Having put on silk and purple, they cannot put on Christ..." (translation of Keenan 1957: 41-42).

${ }^{35}$ Paragraph 5: Continentia vero et pudicitia non in sola carnis integritate consistit, sed etiam in cultus et ornatus honore pariter ac pudore, ut, secundum Apostolum quae innupta est sancta sit et corpore et spiritu. $=$ "But continent and chastity consist not alone in the purity of the body, but also in dignity as well as in modesty of dress and adornment, so that, as the Apostle says, she who is unmarried may be holy both in body and in spirit". Paragraph 12: Fugiant castae virgins et pudciae incestarum cultus, habitus impudicarum, lupanarium insignia, ornamentameretricum. = "Let chaste and modest virgins shun the attire of the unchaste, the clothing of the immodest, the insignia of brothels, the adornments of harlots" (translation of Keenan 1957: 35).

${ }^{36}$ Paragraph 14: Illi (paccatores et apostatae angeli) et oculos circumducto nigrore fucare et genas mendacio ruboris inficere et mutare adulterinis coloribus crinem et expugnare omnem oris et capitis veritatem corruptelae suae impugnatione docuerunt. = "They also taught how to paint the eyes by spreading a black substance around them, and to tinge the cheeks with a counterfeit blush, and to change the hair by false colors, and to drive out all truth from the countenance and head by the assault of their corruption" (translation of Keenan 1957: 43-44).

${ }^{37}$ Paragraph 18: Quasdam non pudet nubentibus interesse, et in illa lascivientium libertate sermonum colloquia incesta miscere, audire quod non licet dicere, observari et esse praesentes inter verba turpia et temulenta convivia, quibus libidinum fomes accenditur, sponsa ad patientiam stupri, ad audaciam sponsus animatur. Quis illi in nuptiis locus est cui animus ad nuptias non est, aut voluntaria illic et laeta esse quae possunt ubi et studia et vota diversa sunt? = "Some are non ashamed to attend weddings and, in the freedom of the wanton discourse there, to take part in the unchaste conversation, to hear what is unbecoming, to say what is not allowed, to look on and to be present in the midst of disgraceful talk and drunken feasts, by which the flame of passion is enkindled, and the bride is incited to tolerate and thebridegroom to become emboldened in lust. What place is there at weddings for one who has no thought of marriage, or what can be pleasant and enjoyable in those occasions wherein desires and interests are so different?" (translation of Keenan 1957: 46-47).

${ }^{38}$ Paragraph 19: Quid vero quae promiscuas balneas adeunt, quaeque oculis ad libidinem curiosis pudori ac pudicitiae corpora dicata prostituunt?. . . Sorditat lavatio, ista, non abluit, nec emundat membra, sed maculat. $=$ "But what is to be said of those who go to the common baths and who prostitute to eyes than are devoted to lust bodies consecrated to chastity and modesty?. . . Such a bath sullies; it does not purify and it does not cleanse the limbs, but stains them" (translation of Keenan 1957: 47). On the permanence of this prohibition to go to the baths in the later Fathers who write for the virgins (for example Jerome), see Radford Ruether 1974: 170 ss. as well as the careful study of Schöllgen 1995: 182-194, where he informs us about the care provided by the Church Fathers to the fact on the basis of his analysis of the Syrian Didascalia (work of the first half of the 3rd century written in Greek but which referred to his subsequent Syrian translation). This same author (based on Bowen 1992: 125-147) points out that the sources credited all kinds of women (and not only the prostitutes) were usually visit the mixed baths, fact which was not well seen by some sectors of the Roman society who saw in it a decadent manifestation of the culture of luxury.

${ }^{39}$ Watson $(1920-1921: 363,366)$ believes that the sense of loss of reality that we find in the Cyprians' Work, the exaggerated behaviour of the virgins that he questions, should both frame on a lack of 
Through an analysis of such characteristics designed to convince virgins that they must adopt certain behavior patterns, I want to highlight some express references made to the institution of marriage without exposing all the differences between Roman and Christian marriage. At no time in Cyprian's work does the Roman marriage become an element of confrontation, debate or criticism, a fact that at first sight can surprise. In fact, one might think that Cyprian could take the opportunity to defend Christian marriage and criticize the secular conception of the matrimonial legislation of Augustus (Lex Iulia de maritandis ordinibus and Lex Papia Poppaea), which refers to the separation, divorce and subsequent marriages of divorced spouses who, as Roman citizens, were required to have a number of children to avoid sanctions, the implications of which were not only patrimonial (see Nörr 1977: 307-334; Ferrero Raditsa 1980: 278 ss. and Astolfi 2006: 191ss.), but in fact also a check on celibacy. However, if we assume that Cyprian is not writing to adversus paganos but to a very specific group of the faithful within his community, it seems natural only to speak about Christian marriage, with references inserted applying as much to the behavior expected of earthly married Christian women as to the virgins married to Christ. His writing aims to "persuade" the Christian virgins and convince them to follow a pattern of life distinct from married Christian women and pagan women. For this reason, I will give attention both to what he tells them as well as how he argues to substantiate and justify his message.

I begin the texts' exposure by reproducing some paragraphs referring to the "wives" of Christ; after having defined virgins ${ }^{40}$ in the fifth paragraph, with the support

experience of Cyprian as Bishop (and this would play to consider that we are facing one of his first works and therefore it still lacks sufficient pastoral experience) as on an artificial development of the issue following a style already present in the rhetorical classics, such as for example in Seneca the Elder. On the same line by setting in the treaties of the 4th century, Cameron (1991: 171-180), who exposed the "discourse of virginity" in the bosom of Christianity in a chapter which, curiously, title as "the rhetoric of paradox". Clark (1995: 38 ss.) says that women who refused to look attractive made a drastic renunciation of identity as women and it implied the renouncing a clear social identity determined by gender.

${ }^{40}$ Paragraph 3: "Flos est ille eccesiastici germinis, decus atque ornamentum gratiae spiritalis, laeta indoles, laudis et honoris opus integrum atque incorrumptum, Dei imago respondens ad sanctimoniam Domini, illustrior portio gregis Christi". = "they are the flower of the tree that is the Church, the beauty and adornment of spiritual grace, the image of God reflecting the holiness of the Lord, the more illustrious part of Christ's flock" (translation of Keenan 1958: 33). Bloch (1987: 23, note 43) stresses the importance of the concept of virginity for the study of misogyny; instead, Guillén (2000: 324) focuses on the theological key to this definition highlighting its charismatic and human aspects. 
of a quote from a letter of Paul to the Corinthians, the Carthaginian Bishop justifies the requirement for a different behavior for a person that has remained celibate -who is called upon to "please God" - over another who has married, aimed to please her husband. Based on the authority of the Apostle, he speaks to the virgin in the following manner:

Paragraph 5: ... . Virgo non esse tantum sed et intellegi debet et credi. Nemo cum virginem viderit, dubitet an virgo sit. Parem se integritas in omnibus praestet, nec bonum mentis corporis cultus infamet. Quid ornata, quid compta procedit, quasi maritum aut habeat aut quaerat?. Timeat potius placere, si virgo est, nec periculum sui appetat quae ad meliora et divina se servat. Quae virum non habet, cui placere se simulet, integre et pure non tantum corpore, sed etiam et sipiritaliter perseveret. Neque enim fas et virginem ad speciem formae suae comi aut de carne et de eius pulcritudine gloriari, cum nulla sit illi magis quam adversus carnem colluctatio et vincendi corporis ac domandi obstinata certatio (Campos 1964: 128). = A virgin should not only be a virgin, but she ought to be known and considered as such. No one on seeing a virgin, should doubt whether she is one. Let her innocence manifest itself equally in all things, and her dress not dishonor the sanctity of her body. Why does she go forth in public adorned, why with her hair dressed, as if she either had a husband or were seeking one? Let her rather fear to be attractive, if she is a virgin, and not desire her own ruin who is keeping herself for higher and divine things. She who has not a husband whom she may pretend to please should persevere in innocence and purity of mind as well as of body. And in truth it is not right for a virgin to adorn herself to set off her charms, nor to glory in her body and its beauty, since there is no struggle greater for such maidens than that against the flesh, and no battle more obstinate than that of conquering and subduing the body. (Translation of Keenan 1958: 35)

We see in the text differentiation between several situations in which women can find themselves: the women seeking a husband, the earthly married and the virgins married with God. With regard to these, the pattern of behavior is quite clear: the virgin must shun ostentation and luxury; she should dress in such a way so you do not notice her fine figure or the beauty of her body ${ }^{41}$, "as having or seeking husband", words that in a derogatory way seem to describe a pattern of behavior of women when they are looking for a husband: to adorn herself, to set off her charms, etc.; in short, highlighting her beauty to be attractive is not acceptable. According to him, the Christian virgins

\footnotetext{
${ }^{41}$ Bloch (1987: 9 ss.) analyzes the misogynistic content of these statements embedded in a wider exposure, which includes other types of sources of the 4th century and after not only in the Christian literature (but omitting Cyprian) and highlights the meaning of hostility towards women and the horror of the body.
} 
cannot follow these forms of conduct; they are not permitted to show off their figure, and this, arguing to the contrary, one might assume is accepted when referring to married Christian women seeking to please their husbands; however, this interpretation is wrong because as we shall see, Cyprian also calls this into question in regard to earthly married women.

And the idea that Christian virgins should be shy and modest and must reject adornment is repeated not only in multiple places ${ }^{42}$, but Cyprian also extends the model of virginal life to Christian women in general, as it can be seen in the text that follows:

Paragraph 8: Locupletem te dicis et divitem. Sed divitiis tuis Paulus occurrit, et ad cultum atque ornatum tuum iusto fine moderandum sua voce praescribit: "Sint, inquit, mulieres cum verecundia et pudicitia componentes se, non in tortis crinibus, neque auro, neque margaritis, aut veste pretiosa, sed ut decet mulieres promittentes castitatem per bonam conversationem" (1 Tim 2, 9-10). Item Petrus ad haec eadem praecepta consentit et dicit: "Sit in muliere non exterior ornamenti aut auri aut vestis cultus sed cultus cordis" (1 Pet. 3, 3-4). Quodsi illi mulieres quoque admonent coercendas et ad ecclesiasticam disciplinam religiosa observatione moderandas quae excusare cultus suos soleant per maritum, quanto id magis observare virginem fas est, cui nulla ornatus sui competat venia, nec derivari in alterum possit mendacium culpae, sed sola ipsa remaneat in crimine (Campos 1964: 129). = You say that you are wealthy and rich. But Paul objects to your wealth, and with his own voice gives directions for keeping your apparel and adornments within right limits: "Let women, he says, array themselves with modesty and sobriety, not with plaited hair, nor gold, nor pearls, nor costly attire, but as it becometh women professing chastity in good conversation" (1 Tim. 2, 910). Peter also agrees with these same precepts and says: "let there be in woman not the outward wearing of ornament or gold or the putting on of apparel, but the ornamentation of the heart" (1 Pet. 3, 3-4). But if Paul advises that married women also, who are accustomed to make their husbands the excuse for their costly attire, should be restrained and kept within bounds by a scrupulous observance of church discipline, how much greater is the obligation of a virgin to render such obedience, who may claim no forbearance for her adornment, and who cannot attribute to another the deception in her fault, but remains herself alone accountable. (Translation of Keenan 1958: 38)

Again in this section Cyprian returns to take into account the distinction between the behavior of married women and virgins. Once more he repeats the alleged argument by Christian married women -who do not support the Carthaginian Father- that they are justified ornaments for the purpose of pleasing their husbands. He, to rebut this

\footnotetext{
${ }^{42}$ See notes 38 ss.
} 
argument and criticize this behavior that he does not consider compliant with Christian discipline, responds with two quotes of Peter and Paul concerning Christian women in abstract (without specifying if single, married, widowed or virgin) quotations which condemned ornamentation, opulence, flaunting of beauty, and lack of modesty. The consequence of this discourse, of employment of this argumentative deductive logic is clear: If beforehand the Apostles had already condemned this way of life in society with respect to Christian women, how could one not condemn it when practiced by such a specific group of women as the virgins. By definition, they cannot claim the necessity of pleasing their earthly husbands to justify the way they behave in society; they have to please to Christ, and he dislikes ornamentation, lack of modesty and flamboyant attire. In short, if all Christian women of rich heritage or at least sufficient wealth to allow the use of precious objects in their attire, should follow the guidelines of the Apostles and practice reasonable moderation in their dress and ornamentation, it is only logical that such discipline should be expected from the virgins as well given that they also form a part of this group ${ }^{43}$.

Similarly, with regard to the exemplary behavior said to be required by not only by those committed by their vows but to all Christian women (virgins, widows, married, single looking for husband) it must be mentioned:

Paragraph 15: Et quidem isto in loco pro timore quem nobis fides suggerit, pro dilectione quam fraternitas exigit, non virgines tantum aut viudas, sed et nuptas puto et omnes omnino feminas admonendas quod opus Dei et factura eius et plastica adulterari nullo modo debeat adhibito flauo colore vel nigro pulvere vel rubore aut quolibet denique liniamenta nativa corrumpente medicamine. ...Ut enim impudica circa homines et incesta fucis lenocinantibus non sis, corruptis violatisque quae Dei sunt, peior adultera detineris. Quod ornari te putas, quod putas comi, impugnatio est ista divini operis, praevaricatio est veritatis (Campos 1964: 134). = And indeed at this point in my address, because of the fear of God which faith excites in me, and the affection which brotherhood demands, I think that not only virgins and widows but married women also, and all women in general should be warned that the work of God and His creature and image should

\footnotetext{
${ }^{43}$ As it is well known, deduction is a form of argument consistent to move from a general framework - in the case of all Christian women - one individual group- the virgins- in such a way that for Cyprian applies this overwhelming logic to condemn the virgins and subsume them within the group that has previously received the general condemnation. In respect of this way of argumentation by the Roman jurists see, for example, de Churruca - Mentxaka: 2007: 174, and Horak 1969: 77 ss.
} 
in no way be falsified by employing yellow coloring or black powder or rouge, or finally, any cosmetic at all that spoils the natural features ... Although you may not be immodest toward men and unchaste through your alluring cosmetics, in corrupting and dishonoring the things that are God's you are counted a worse adulteress! As for your thinking that you are adorned, that you are beautifully dressed, this is an assault upon the divine work, a violation of the truth. (Translation of Keenan 1958: 44)

In my opinion, this extract clearly demonstrates Cyprian's draconian and punitive attitude to Christian women who decide to transgress the moral code that he advocates. Whilst Cyprian acknowledges the view point of the common Christian or lay man; namely that jewelry does not lead women into sin yet, he argues that when women abuse ornamentation, they subvert God's divine work and commit the worst form of adultery. This is because any manipulation of the Lord's natural creation is considered fundamentally corrupt by Cyprian ${ }^{44}$. The mere act of painting, decorating and sprucing is to deface the work of God, it is for him an act which makes the author not only into an adulteress but, into the worst kind of adulteress. Obviously, with such a strong statement, Cyprian is making an extremely negative assessment of the Christian woman who chooses to adorn herself, which does not condescend but is relentless in calling her for her use of cosmetics ${ }^{45}$ not only impudica ${ }^{46}$ and incesta ${ }^{47}$ but adultera (peior adultera detineris). It is clear that any woman of the time would understand the message perfectly given that Cyprian delivers it in such a pejorative manner. Equally in his manner of describing and presenting his views of society so negatively, Cyprian casts upon them a burden so heavy that few would dare to try to cope with it; if the woman dares to adorn herself, she will be considered and evaluated by the authorities of their religious creed, playing with the polysemy of the term adulterare, as the worst possible

\footnotetext{
${ }^{44}$ As it is well known, adulterare in addition to being a technical term used to refer to commit adultery, also has the sense of to corrupt, debase or pervert, to mix, to falsify, etc.; on these meanings see for example: Oxford Latin Dictionary 1982: 59. It examines the presence of this idea already in Tertullian and what this means as well as their subsequent settlement in medieval literature (Bloch 1987: 12-13).

${ }^{45} \mathrm{Keep}$ in account that uses lenocinor to refer to this. On the senses of the term, see Oxford Latin Dictionary 1982: 1016.

${ }^{46}$ On the senses of the term as immoral, having no sense of shame, etc., see for example: Oxford Latin Dictionary 1982: 853.

${ }^{47}$ With the meanings of: impure, unrighteous, guilty of incest, etc. vid. for example: Oxford Latin Dictionary 1982: 865.
} 
adulteress $^{48}$. Therefore, if Christian women and virgins want to be consistent with the doctrine established by their religion, they must renounce any kind of ornament, they must reject care of the body; in the event this is not done, Cyprian ensures that she will be blamed, denigrated and, consequently, condemned.

Yet, this idea of considering as adulterous the virgins who do not act in accordance with the discipline but are adorned and therefore corrupt is not a statement that we find by chance in this paragraph. Indeed, it gives the impression that Cyprian has a very clear idea that he repeats in another place in which, always with the same dismissive and pejorative rhetorical style, reiterates that these behaviors are reprehensible, and considers transforming them into widows before they are married and as adulteresses, not in respect to their husbands, but to Christ.

Paragraph 20: Sic ergo frequenter Ecclesia virgines suas plangit, sic ad infames earum ac detestabiles fabulas ingemiscit, sic flos virginum exstinguitur, honor continentiae ac pudor caeditur, gloria omnis ac dignitas profanatur;. Sic se expugnator inimicus per artes suas inserit; sic insidiis per se occulta fallentibus diabolus obrepit, sic, dum ordinari cultius, dum liberius evagari virgines volunt, esse virgines desinunt, furtituo dedecore corruptae, viduae antequeam nuptae, non mariti sed Christi adulterae... (Campos 1964: 137-138)

Thus, we see how the Church frequently bewails her virgins; hence, she groans over the notorious and detestable gossip about them; hence the flower of virginity is destroyed, the honor and modesty of continence are killed, all glory and dignity are profaned. Hence the conquering enemy insinuates himself by his wiles; hence by snares that deceive through secret ways the devil creeps in; hence virgins in desiring to be adorned more elegantly, to go about more freely, cease to be virgins, being corrupted by a hidden shame, widows before they are brides, adulteresses not to a husband but to Christ. (Translation of Keenan 1958: 48)

Curiously, on both occasions the Carthaginian Bishop does not use the term adulteress to describe in a technical sense a criminal act that deserves punishment, for example in the fourth letter, in which the cohabitation of a virgin with a deacon is considered as such, which to some extent was legal in accordance with Roman law if we accept the fiction established by Cyprian that the virgin was not a maiden ${ }^{49}$ but was a

\footnotetext{
${ }^{48}$ Radford Ruether (1974: 163) notes that in the Church Fathers basically have three images of women: woman as whore, woman as wife and woman as virgin.

${ }^{49}$ It must be borne in mind that the relationship with a virgin is expressly qualified in legal sources as stuprum and not adultery: Dig. 48, 5, 6, 1 (Papin. Adult. 1): . . Lex stuprum et adultuerium promiscue. . .
} 
woman married with Christ, and, consequently, to join with a male she was committing adultery with respect to her husband who was Christ.

In the two paragraphs above, it seems obvious that the terms adultera-adulterare are not used with the legal meaning that typifies criminally prosecutable behavior under Roman law but he uses it to describe what he considers unworthy, outside the established discipline and moral practice expected a modest woman; such behavior takes place if the virgin is adorned, if she goes about freely, in short if she practices a form of lifestyle far removed from the guidelines requiring Christian discipline, even if she by no means has relations with men, according to Cyprian's view she becomes a woman impudica and incesta and deserves at least, at minimum to be considered an adulteress $^{50}$. In my opinion, the Carthaginian father makes fully conscious use of these terms loaded with meaning and legally linked to sexual behavior subject to prosecution in Roman society (impudica, incesta, lenocinor, adultera) to justify them, based on the need to condemn the behavior of the virgins; however this condemnation could be described as religious and moral because as we will see in the next paragraph is not fully developed into a specific sanction, although it is aimed at expulsion from the ordo.

The African Father is probably aware of the difficulty of imposing this coy, austere, humble and moderate behavior on all Christian women and, perhaps for this reason, does not dare to take the step of condemning all Christians women to continue practicing it; therefore, in another paragraph of the letter, he redirects his claims and

apellat; sed proprie adulterium in nupta committitur; ...stuprum vero in virginem viuduamve committitur $=$ "The law refers to stuprum and adultery indiscriminately.... . but properly speaking adultery is committed with a married woman, .... . stuprum however, is committed against a virgin or a widow" (translation of Watson 1985: 805). See, for example, Pfaff 1931: 423-424; Molè 1971: 582-586; Rizzelli1997: 171 ss.; Botta 2004; and Puliatti 2007: 4498-4519.

${ }^{50}$ To appreciate the condemnation that has been given this institution it is interesting to see the example included in Cyprian, Epist., 55, 26, 1 describing punishable conduct accompanying Novatian, which (as it is well known Cyprian had a serious confrontation with him on the readmission within the Church of apostates (lapsi) fallen as a result of non-compliance with the Edict of the Emperor Decius (249-250?) ) for Cyprian's view it was excessively rigorist, says: "let him separate defrauders and adulterers from his side and from his company since the case of an adulterer is much more serious and much worse than that of the one who has received a certificate since the latter sinned under duress; the former, of his free will; the latter, thinking that it was enough for him that he did not sacrifice, has been deceived by error; the former, the destroyer of the marriage of another or the one, having entered a house of ill repute in the sewer and muddy whirlpool, has violated wit base impurities a body sanctified and a temple of God, [...]" (translation of Bernard Donna 1964: 151). 
acknowledges that he is addressing the virgins for which he already directs a sanction and abandons to their fate the married women that adorn themselves with a desire to please their spouses. This text reads as follows:

\begin{abstract}
Paragraph 17: Non metuis, oro, quae talis es, ne cum resurrectionis dies venerit, artifex tuus non recognoscat, ad sua proemia et promissa venientem removeat et excludat et increpans vigore censoris et iudicis dicat: "Opus hoc menum non est, nec imago nostra est". Cutem falso medicamine polluisti, crimen adultero colore mutasti, expugnata est mendacio facies, figura corrupta est, vultus alienus est. Deum videre non poteris, quando oculi tibi non sunt quos Deus fecit, sed quod dibolus infecit......Viderint quid sibi nuptae per placendi studium de coniugum solatio blandiantur; quos dum in excusationem suam proferunt, ad societatem criminosae consennis asciscunt. Virgines certe, quibus hic sermo nunc consulit, quae se ieusmodi artibus compserint, inter virgines non putem debere numerari, sed tanquam contactas oves et morbidas pecudes a saucio et puro grege virginitatis arceri, ne contagio suo cetereas polluant dum simul degunt, ne perdant alias quaecumque perierunt (Campos 1964: 135-136) = Do you not fear, I ask, being such as you are, that when the day of resurrection comes, your Maker may not recognize you, that He may set you aside when you come for His rewards and promises, and may exclude you and, reproving you with the severity of a censor and judge, may say: "This work is not mine nor is this our image". You have defiled your skin with lying cosmetics; you have changed your hair with an adulterous color; your face is overcome by falsehoods; your appearance is corrupted; your countenance is that of another. You cannot see God since your eyes are not those which God has made, but which the devil has infected . . . Married women should consider to what extent they are deceiving themselves with regard to the comfort that they give to their husbands through their efforts to please them; for in putting them forward as their excuse, they are making them cooperate in a guilty agreement. Assuredly, virgins, to whom this does not pertain, who have adorned themselves by devices of this sort, should not be numbered among virgins, in my opinion, but, like tainted sheep and diseased cattle, they should be kept apart from the pure and holy flock of virgins, lest while they are together they corrupt others by their contact, lest they who have themselves perished ruin others. (Translation of Keenan 1958: 45-46)
\end{abstract}

Cyprian has to end up accepting that it is impossible to require the same forms of life for all Christian women. All of them, if they are painted and decorated, are in danger of being reprimanded on the day of resurrection when they are told that they have defaced their skin or have dyed their hair ${ }^{51}$. To avoid being recriminated, he recommends to the virgins that are adorned; if there are virgins who do so, advocates

\footnotetext{
${ }^{51}$ I wish to stress that Cyprian goes once again to the term adulterare (crimen adultero colore mutasti) to refer to the case, which although understandable given their meanings, from my point of view, implies an additional negative charge.
} 
that they are not considered true virgins and the separate assertion which, to some extent, already includes the idea that they should be punished with the loss of status, although still does not specify under what conditions ${ }^{52}$. In contrast to them are the married women that if they do not follow his advice and adorn themselves (and again emerges the oft repeated argument put forward for married women such as we have seen in previous texts: they follow the customs in order to please their husbands) they will have to fend for themselves and risk the consequences of their actions.

\section{Final synthesis}

I think that what I have exposed permits making the following conclusions:

a. The great importance that Cyprian gives to virginity, insofar as he makes virgins the target of one of his works, reminds us of the wide dissemination of this way of life in Carthage in the mid-3rd century Christian society, particularly among women of a certain economic capacity such that they are accustomed to the usual patterns of life practiced by their high social standing.

b. For the North African Bishop, virginity does not only mean staying chaste but maintaining a demure and austere lifestyle; therefore, he condemns the use of perfumes, luxury in dress, ornamentation, etc.; he also is opposed to visits to the baths as well as women's body care: a beautiful body that is adorned is more attractive than one that is not and subjects their owners to greater sexual temptations that at any given time can make them abandon their chastity.

c. He has no doubt either in trying to extend these guidelines - supposedly addressed only to the virgins - to all Christian women, although fully aware that married

\footnotetext{
${ }^{52}$ The idea of penalizing some of these behaviors gelled as it is evident from Schöllgen (1995: 190) who collects the sanctions laid down from the 4th century in the bosom of the Church not only for ascetics who come to the baths against prohibition (which lost its status) but also of the laity or clergy (who are excommunicates). The sanctions came to secular legislation and the Emperor Justinian in CJ 5, 17, 11, 2 allowed the repudiation, with loss of women's dowry, if bathing with another man.
} 
women develop different habits; because, for example, it is usual for them to take care of their body and ornament themselves, Cyprian believes that if they are in truth Christian they should not do these things. To condemn this behavior he argues, sometimes deductively, relying on biblical writings of the New Testament, specifically of the Apostles Peter and Paul, in such a way that these quotations and the authority they convey help to justify the message that he hopes to transmit.

d. In addition to these argumentative resources, he uses a lexicon in which terms such as impudica, incesta, lenocinor or adultera are present (although the last is not used in its legal technical sense), words that are loaded with profound negative sense; serving his purpose is that the recipients of his writings have knowledge of all the meanings of this terminology and this makes them acknowledge the condemnation that accompanies their behavior and constructed though his use of the doctrine of sin and punishment, moral though still aimed at removing the status of virgin from those that do not adhere to the discipline set by the Church must receive.

\section{References}

Astolfi, Ricardo. 2006. Il matrimonio nel diritto romano classico. Padova: Cedam.

Botta, Fabio. 2004. "Per vim inferre": studi su stuprum violento e raptus nel diritto romano e bizantino. Cagliari: Edizioni AV.

Bloch, Howard. 1987. "Medieval Misogyny. Woman as Riot". Representations 20: 124.

Bowen Ward, Roy. 1992. "Women in Roman Baths". Harvard Theological Review 85: 125-147.

Brown, Peter. 1993. El cuerpo y la sociedad: los hombres, las mujeres y la renuncia sexual en el cristianismo primitivo. Barcelona: Muchnik.

1985. "The Notion of Virginity in the Early Church". Christian Spirituality. Origins to the Twelfth Century. Eds. Mcginn Bernard, Meyendorff John y Leclercq Jean. New York: Crossroad. 427-428. 
Cameron, Averil. 1991. Christianity and the Rhetoric of Empire: The Devolpment of Christian Discourse. Berkeley: University of California Press.

Campos, Julio. 1964. Obras de San Cipriano. Edición bilingüe. Madrid: Biblioteca de autores cristianos.

Castelli, Elisabeth. 1986. "Virginity and its Meaning for Women's Sexuality in Early Christianity". Journal of Feminist Studies in Religion 2: 61-88.

Clark, Gillian. 1995. "Women and Ascetism in Late Antiquity: The Refusal of Status and Gender". Ascetism. Eds. Wimbush Vincent L. y Valantasis Richard. Oxford: Oxford University Press 1995. 33-48.

Clarke, Elisabeth Ann. 1987. Women in the Early Church. Wilmington: Michael Glazier.

De Churruca, Juan y Mentxaka, Rosa. 2007. Introducción histórica al Derecho Romano (9. ed). Bilbao: Universidad de Deusto.

Dauvillier, Jean. 1970. Les Temps apostoliques. ler. siècle. Paris: Sirey.

Deléani, Simone. 2007. S. Cyprien, Lettres 1-20. Introduction, texte, traduction et commentaire. Paris: Institut d'Études Augustiniennes.

Dell'Osso, Carlo. 2006. Cipriano vescovo di Cartagine. Lettere 1-50. Introduzione di Carlo Dell'Osso. Traduzione di Maria Vincelli. Note di Giovanna Taponecco. Roma: Citta Nuova.

Bernard Donna, Sister Rose. 1946. "Notes on Cyprian the De habitu virginum. Its Source and Influence". Traditio 4: 399-407. . 1964. Saint Cyprian, Letters (1-81). Washington: Catholic University of American Press.

Dunn, Geoffrey D. 2005 a. "Cyprian and Women in Time of Persecution". Journal of Ecclesiastical History 4: 205-225.

2005 b. "Widows and Other Women in the Pastoral Ministry of Cyprian of Carthage". Augustinianum 45: 295-307.

Gerlitz, Peter. 1989. “Keuschheit”. Theologische Realenzyklopädie, vol. 18: 113-134.

Elm, Susanna. 1994 = reprint 2004, Virgins of God. The Making of Asceticism in Late Antiquity. Oxford: Oxford University Press.

Fernández Ubiña, José. 1981. "Comportamientos y alternativas cristianas en una época de crisis: el testimonio de Cipriano". Memorias de Historia Antigua 5: 213-226. 
García Villoslada, Ricardo. 1978. Historia de la Iglesia en España. Vol. 1. Madrid: Biblioteca de autores cristianos.

Giesen, Heinz. 1996. "Jungfräulichkeit. II Biblisch-theologisch". Lexikon für Theologie und Kirche, vol. 5. Freiburg - Basel - Roma - Wien: Herder: 1096-1097.

Guillén, Ferdinand. 2000. "Le habitu virginum de Saint Cyprien: pour une chasteté chrétienne inculturée". Annales de l'école theologique Saint-Cyprien 7: 319-331.

Gülzow Henneke, Wlosok Antonie. 1997. "Caecilius Cyprianus (qui et Thascius), (Apologetische Schriften)". Handbuch der lateineischen Literatur der Antike. Ed. Lebrecht Schmidt Peter, Vierter Band: Ed. Sallmann Klaus. Die Literatur des Umbruchs. Von der römischen zur christlichen Literatur 117-284 n. Ch., München: C. H. Beck: 532-577.

Horak, Franz. 1969. Rationes decidendi. Entscheidungsbegründungen bei den alteren romischen Juristen bis Labeo. 1. Band. Aalen: Scientia Verlag.

Johnson, Lawrence J. 2009. Workshship in the Early Chruch. An Anthology of Historical Sources, vol. 1. Collegeville: Liturgical Press.

Keenan, Sister Angela Elisabeth. 1932. Thasci Caecili Cypriani De Habitu virginum. Washington: The Catholic University of America Press. Patristic Studies 34.

1958. Saint Cyprian, Treatises. Deferrari, Transl. and Ed. Roy Joseph. New York: The Catholic University of America Press.

Krawiec, Rebecca. 2002. Shenoute and the Women of the White Monastery: Egyptian Monasticism in Late Antiquity. Oxford-New York: Oxford University Press.

MacDonald, Margaret Y. 1996. Early Christian Women and Pagan Opinion. The Power of the Hysterical Woman. Cambridge: Cambridge University Press.

Martínez, Le P. Francesco. 1913. L'Ascétisme chrétien pendante les trois premiers siècles de l'Église. Paris: G. Beauchesne.

McNamara, Jo Ann. 1976. "Sexual Equality and the Cult of Virginity in Early Christian Thought". Feminist Studies 3: 145-158.

1979. "Wifes and Widows in Early Christian Thought". International Journal of Women's Studies 2: 575-592.

Mentxaka, Rosa. 2010. Cipriano de Cartago y las vírgenes consagradas. Observaciones histórico-jurídicas a la carta cuarta de sus Epistulae. Lecce: Edizioni Grifo. 
2013. "Aproximación a la situación de la mujer en el cristianismo primitivo". Mulier. Algunas Historias e Instituciones de Derecho Romano. Eds. Rosalía Rodríguez López y María José Bravo Bosch. Madrid: Dykinson. 53-80.

Molè, Marcello. 1971. “stuprum”. NNDI, vol. 18: Torino: UTET: 989-994.

Nörr, Dieter. 1977. "Planung in der Antike. Über die Ehegesetze des Augustus". Freiheit und Sachzwang. Beitr. zu Ehren Helmut Schelskys. Opladen: Westdeutscher. Verlag: 307-334.

Oxford Latin Dictionary. 1982. Ed. P. G. W. Glare. Oxford: Oxford University Press.

Pedregal Rodríguez, Amparo. 2007. "Ancilla dei. El discurso cristiano sobre la sumisión femenina”. Studia historica. Historia Antigua 25: 417-434.

Pfaff, Ivo. 1931. “stuprum”. PWRE, vol. IV A 1. Stuttgart: 423-424.

Puliatti, Salvatore. 2007. "Il diritto penale dell 'ultima legislazione giustinianea. I crimini contro la moralità e la famiglia. I reati sessuali: adulterio, stupro, lenocinio". Fides, Humanitas, Ius. Studi in onori di L. Labruna, vol. VII, Napoli: Editoriale Scientifica: 4491-4523.

Quasten, Johannes. 2001. Patrología, 1. Hasta el concilio de Nicea, (6 ed.). Madrid: Biblioteca de autores cristianos.

Radford Ruether, Rosemary. 1974. "Mysogynism and Virginal Feminism in the Fathers of the Church". Religion and Sexism: Images of Women in the Jewish and Christian Traditions. New York. Simon and Schuster: 150-183.

Raditsa, Leo Ferrero. 1980. "Augustus' Legislation Concerning Marriage, Procreation, Love Affairs and Adultery". Aufstieg und Niedergang der Römischen Welt. II, 13. Berlin-New York: Walter de Gruyter: 278-339.

Ramis, Gabriel. 1990. La consagración de la mujer en las liturgias occidentales. Roma: Edizioni Liturgiche.

Ramos Lissón, Domingo. 2009. Compendio de Historia de la Iglesia antigua. Pamplona: Ediciones Universidad de Navarra.

Rizzelli, Giunio. 1997. La lex Iulia de adulteriis. Studi sulla disciplina di adulterium, lenocinium, stuprum. Lecce: Edizioni del Grifo.

Schollgen, Georg. 1984. Ecclesia sordida?, Zur Frage der sozialen Schichtung frühchristlicher Gemeinden am Beispiel Karthagos zur Zeit Tertullians. Jahrbuch für Antike und Christentum. Ergänzugnsband 12, Münster: Aschendorffsche Verlagsbuchhandlung. 
1995. "Balnea mixta. Entwicklungen der spätantiken Bademoral im Spiegel der Textüberlieferung der Syrischen Didaskalie". Panchaia, Festschr. für K. Traede $=J b A C$, ERgBd. 22: 182-194.

2001. "Jungfräulichkeit". Reallexikon für Antike und Christetum, vol. 19 Stuttgart: 523-592.

Stahlmann, Ines. 1997. Der gefesselte Sexus. Weibliche Keuschheit und Askese im Westen des römischen Reiches. Berlin: Akademie Verlag GmbH.

Testard, Maurice. 1981. Chrétiens latins despremiers siècles. La littérature et la vie. Paris: Les Belles Lettres.

Tibiletti, Carlo. 1979. "Ascetismo e storia della salvezza nel "De habitu virginum" di Cipriano". Augustinianum 19: 431-442.

Viciano, Albert. 2006. "El papel de la mujer en la teología de Cipriano de Cartago", Antigüedad y cristianismo 23: Espacio y tiempo en la percepción de la antigüedad tardía: homenaje al profesor Antonino González Blanco, "In maturitate aetatis ad prudentiam”. Coords. María Elena Conde Guerri, Rafael González Fernández y Alejandro Egea Vivancos. Murcia: Servicio de Publicaciones: 569-582.

Vizmanos, Francisco de B. S. J. 1949 = reedition 2009. Las vírgenes cristianas de la iglesia primitiva. Estudio histórico y Antología patrística. Madrid: Biblioteca de autores cristianos.

Watson, Alan. 1985. The Digest of Justinian (with Latin text. Eds. Theodor Mommsen y Paul Krüger), vol. IV. Philadelphia: University of Pennsylvania Press.

Watson, Edward William. 1920-1921. "The De habitu virginum of St. Cyprian". Journal of theological studies 22: 361-367. 